\title{
De heróis e de mártires: visões de mundo e acidente de trabalho no setor de rochas ornamentais
}

\author{
Maria das Graças Barbosa Moulin ${ }^{1}$ \\ Universidade Federal do Espírito Santo
}

\begin{abstract}
O artigo analisa a construção social de trabalhadores e de proprietários de terras que migram da posição de rurais para a de trabalhadores industriais e empresários, nos primórdios do processo de extração e beneficiamento de mármore e granito na região sul do Espírito Santo. Trata-se de atividade perigosa que resultou em elevada taxa de acidentes fatais e mutilações. Objetiva investigar a possibilidade de a tolerância social aos acidentes estar ancorada em aspectos culturais, por valores compartilhados, que tornam o acidente "passível de ser sofrido". Utiliza o recurso metodológico das histórias de vida de trabalhadores aposentados e empresários idosos, reconstruindo os "modos de andar a vida" a partir da memória. O trabalho, bruto e rude, exigia provas de saúde e virilidade; a técnica era a de ensaio e erro. Os trabalhadores sentiam-se "heróis" por conseguirem suportar o cotidiano penoso do trabalho, sentiam orgulho por terem saído da roça e serem "de indústria". A noção de "homem honrado" era o de bom trabalhador e de provedor da família. Perder o emprego significaria a perda da sobrevivência material e simbólica: a morte em vida. Sem outras oportunidades, os "heróis" tornaram-se "mártires", dados as mortes e os sofrimentos causados pelo trabalho.
\end{abstract}

Palavras-chave: Acidente de trabalho, Saúde do trabalhador, Trabalho no setor de rochas, Memória e cultura.

Of heroes and martyrs: visions of the world and work accidents in the ornamental rocks sector

The article analyses the social construction of workers and land owners that change from a rural status to the position of industrial workers and entrepreneurs during the early period of the process of extracting and benefiting marble and granite in the south of Espirito Santo. It is a dangerous activity which has resulted in an elevated rate of fatal and injuring accidents. It is the objective of this paper to investigate the possibility of seeing the social tolerance to the accidents as being anchored on cultural aspects that make the accident "acceptable". The methodological approach used was the collection Life Stories of the retired workers and old businessmen, rebuilding their "way of life" from memory. The work, rude and brute, demanded testimonies of health and virility; the technique was trial and error. The workers felt like "heroes" for being able to endure; they were proud for having left the country to become "industry men". The notion of "honorable men" was that of good worker and family provider. Thus, losing the job would mean losing material and symbolic survival: death in life. Without other opportunities, the "heroes" became martyrs due to the deaths and suffering caused by work.

Keywords: Work accident, Worker health, Work in the rock sector, Memory and culture.

\author{
Como Encarar a Morte \\ (...) À meia distância \\ Claridade infusa na sombra, \\ treva implícita na claridade? \\ Quem ousa dizer o que viu, \\ se não viu a não ser em sonho? \\ Mas insones tornamos a vê-lo \\ e um vago arrepio vara \\ a mais íntima pele do homem. \\ A superfície jaz tranqüila. (...) \\ Carlos Drummond de Andrade
}




\section{Introdução}

$\mathrm{O}$

processos de trabalho relacionados à extração, ao beneficiamento e ao transporte de mármore e de granito realizados no sul do Estado do Espírito Santo são reconhecidamente perigosos e penosos. As atividades, executadas a céu aberto, sob o excessivo calor da região, são caracterizadas por elevado ruído, presença constante de pó de mármore e utilização de dinamites. A face mais trágica se traduz na ocorrência de acidentes fatais e mutiladores, a ponto de a localidade de Itaoca, distrito de Cachoeiro de Itapemirim, ser conhecida também por "Vila das Viúvas".

São acidentes que, por sua gravidade, atingem não só trabalhadores, mas também moradores das pequenas localidades. Por exemplo, quando, em 20 de dezembro de 1997, dois trabalhadores, "...conduziam dinamites e estopim de dinamite na pá carregadeira quando estes explodiram no caminho", conforme registro de uma CAT (Comunicação de Acidente de Trabalho) obtida junto ao sindicato de trabalhadores da categoria ${ }^{2}$. Nesse acidente, morreram dois trabalhadores com idades de 19 e 39 anos. Os corpos, dilacerados, partidos em vários pedaços, podiam ser avistados em cima de árvores - pedaços de carne sem nenhuma forma que os identificasse, conforme as fotos tiradas por bombeiros que socorreram as vítimas. A explosão atingiu casa, queimou uma árvore inteira. São acidentes que não circunscrevem os efeitos apenas contra as vítimas e suas famílias, mas toda a comunidade é literalmente atingida e impactada. ${ }^{3}$

Uma questão se impõe ao pesquisador: como os trabalhadores, suas famílias e toda uma comunidade suportam conviver diariamente com uma atividade de trabalho que pode matar ou mutilar não só os que nela labutam, mas também moradores e até crianças?

$\mathrm{Na}$ tentativa de compreensão da questão, tratamos, neste artigo, de estudar os primórdios da atividade, quando se alicerça, pedra sobre pedra, uma visão de mundo em que tais ocorrências se inscrevem em uma ordem, se não de normalidade, de uma fatalidade (ainda) inescapável.

Ao procedermos à reconstituição histórica, entendemos que a análise do acidente de trabalho não se limita aos atos e às condições inseguros. Já nos primórdios da atividade, ela encontra-se submetida à lógica do processo de produção, de extração de lucro, em um tipo de organização do trabalho com características de improvisação e de informalidade, em que trabalhadores estavam cotidianamente colocando a suas vidas em risco. Ou seja, compreendemos, conforme Freitas (2001), a importância crucial de se analisar "as falhas gerenciais e organizacionais que permeiam as relações sociais no trabalho e o modo de operação das indústrias" (p. 90); de enfatizar as condições, a organização e relações sociais de produção quando se investiga um acidente de trabalho.

No entanto, para além da análise do trabalho realizado no chão das pedreiras, o que ressaltamos aqui é a intrincada tessitura cultural da população industrial em formação, que, a partir dos valores que elege e hierarquiza, ajuda a tornar o acidente uma realidade suportável. Mais, precisamente, buscamos compreender se e como a cultura e a história desses trabalhadores contribuem na adoção de atitudes que tornam o convívio com o risco de acidente e do adoecer algo da ordem da fatalidade, enriquecendo a análise dos acidentes com a compreensão de que a inserção no trabalho atravessa outros (ou praticamente todos) fatos dos modos de andar a vida.

2 Sindicato dos Trabalhadores em Indústrias de Extração e Beneficiamento do Mármore, Granito e Calcário do Espírito Santo (Sindimármore).

3 Relatos do banco de dados da tese da autora na área de saúde pública (Moulin, 2006). 


\section{Trabalhadores, cultura e modernidade}

Faz-se necessário compreender a noção de cultura, conforme Duarte (1986): não por seus elementos ('traços', 'comportamentos', 'normas', atitudes', 'regras', 'papéis', 'obras' etc.) mas sim pelos modos de articulação do sentido, da significação, que permitem justamente que os elementos existam enquanto tais, parte de uma totalidade simbólica” (p. 120). É o conjunto de princípios que, articulados, subjaz às manifestações empíricas da atividade de um grupo.

O autor aponta traços de identidade das classes trabalhadoras: na valoração sobre os vínculos e pertencimentos à família; sobre o exercício pelo homem de um certo tipo de "trabalho" (principalmente aquele que despende energia física) e de um sentimento e de práticas de pertencimento a um grupo de co-habitantes. Há aqui a preeminência do grupo sobre o indivíduo e a observância de regras de precedência hierárquica nítidas, como as de gênero, classe, idade ou prestígio profissional (Duarte, 1986, p. 132). Assinalar essas peculiaridades implica evidenciar que são características diferenciadas das classes médias "letradas" da modernidade que têm como valor preeminente $o$ indivíduo e não valores hierárquicos. Valores hierárquicos dizem respeito à maneira como se configuram as relações (idéias e valores) no interior de um determinado sistema.

Tomando por referência a análise de Dumont (1993) sobre as sociedades de castas da Índia - holista (sistema em que o todo predispõe às partes) em oposição à individualista (em que subordinamos a noção de totalidade ao individualismo) -, Duarte (1983) aponta que há, na sociedade moderna complexa, um horizonte de valores no qual estão nossas crenças nos indivíduos, em nosso valor intrínseco, na ciência, na capacidade reflexiva da razão, que acreditamos serem valores cruciais; valores esses que se traduzem numa verdadeira "religião laica", que ele denomina "culto do eu".

Assim, a especificidade da temporalidade moderna seria a da linearidade radical, a idéia de um tempo infinito, ou seja: a idéia de que não há um começo nem um fim dos tempos, mas que nós temos um tempo infinitamente extenso e que a nossa própria vida se coloca nessa seqüência. Se, por exemplo, num tempo circular, a morte é parte do ciclo, em um tempo linear a morte significa o fim. Por isso evitamos pensar na morte. Temos, por perspectiva, pensar-nos imortais; escondemos os moribundos. Conforme Ariès (1989), a morte tornou-se um tabu, evita-se falar nela em público, tornou-se um interdito. Segundo o autor, uma nova sociabilidade se exige aos enlutados que sobreviveram ao moribundo: "o sobrevivente infeliz deve ocultar o seu desgosto, renunciar a retirar-se para uma solidão que o trairia, e continuar sem interrupção a sua vida de relações, de trabalho e de lazeres" (Ariès, 1989, p. 161).

Essas diferentes visões de mundo (hierárquicas e individualistas) estão em permanente tensão e contradição na sociedade complexa em que vivemos. Nesse sentido, embora estejamos todos, pesquisadores e trabalhadores, inseridos numa "cultura ocidental moderna" dita hegemônica, com valorações individualizantes e igualitárias, o autor nos chama a atenção para as subculturas - o prefixo "sub" não quer dizer inferior, mas sinaliza culturas diferenciadas daquela que costumamos naturalizar como predominante. Trata-se do esforço de evidenciar "outros", onde vemos "mesmos", ou seja, evidenciar a especificidade de uma determinada cultura, em um espaço e em um tempo onde tudo pode nos parecer tão próximo e tão familiar (Duarte, 1986; Velho, 1987), por exemplo, os trabalhadores do setor de rochas.

No mundo do trabalho nas pedreiras, em transição do rural para o industrial, como o que estudamos, em que sobrevivem marcas culturais tradicionais e em permanente contato e contradição com as marcas culturais modernas, como a vida e a morte são vivenciadas? Trata-se de uma cultura específica, em que vida, trabalho e morte têm seus significados 
próprios, articulados simbolicamente, fornecendo sentido a um cotidiano aparentemente exótico para o pesquisador: trabalhar para viver e morrer no trabalho.

\section{As estradas e vielas da compreensão}

Tornar-se trabalhador de indústria, mais do que o direito ao salário mensal, envolve uma série de idéias, valores e significações que, articulados, formam visões de mundo, que tornaram possível compreender a importância do trabalho, articulado à vida e à morte de trabalhadores do setor. Independente de pertenças culturais, vários autores evidenciam o trabalho como um fato social estruturante tanto do ponto de vista do processo de construção de identidade dos sujeitos modernos, quanto do ponto de vista do processo saúde-doença (Jardim, 1997; Seligmann-Silva, 1994; Silva Filho et al., 1993).

Para proceder à reconstituição histórica dos primórdios do processo de trabalho com mármore e granito, utilizamos entrevistas semi-estruturadas e histórias de vida tópicas (Minayo, 1992) com ênfase na vida de trabalho - com três trabalhadores aposentados e dois empresários, ainda na ativa, com mais de 70 anos de idade. Além disso, entrevistamos três sindicalistas que esclareceram as lacunas deixadas pelas entrevistas com os trabalhadores mais idosos. O tema norteador foi: como começou a atividade, com que recursos, técnicas, conhecimentos, pessoas? Ao mesmo tempo, interessou-nos a intercessão da vida cotidiana dos trabalhadores fora do trabalho e da vivência ou não de agravos à saúde, além do tipo de assistência prestada.

A escolha das histórias de vida como trilhas de compreensão da nossa questão implica evidenciar memórias individuais. Embora as histórias sejam individuais e reflitam a memória singular do entrevistado, não há possibilidade de se pensar a memória de outra forma que não seja como um fenômeno coletivo, social e sujeito a transformações, mudanças e (re)interpretações (Halbwachs, 2006). No entanto, em que pese o caráter fluido da memória, há nas entrevistas algo de invariante, um ponto ao qual o relato sempre retorna, algo em que, segundo Pollack (1992), "o trabalho de solidificação da memória foi tão importante que impossibilitou a ocorrência de mudanças. Em certo sentido, determinado número de elementos torna-se realidade, passam a fazer parte da própria essência da pessoa" (p. 1).

A memória, de acordo com o autor, caracteriza-se por ser seletiva - nem tudo fica gravado, por sofrer flutuações do momento em que é articulada e por se tratar de um fenômeno construído social e individualmente. Pollack (1992) ressalta a "(...) ligação fenomenológica muito estreita entre a memória e o sentimento de identidade (...)". O autor enumera três elementos essenciais do ponto de vista da construção da identidade: 1) a unidade física - o sentimento de ter fronteiras físicas, no caso do corpo da pessoa, ou fronteiras de pertencimento ao grupo, no caso do coletivo; 2) continuidade dentro do tempo, tanto no sentido físico da palavra, quanto no sentido moral e psicológico; e 3) o sentimento de coerência (ou pelo menos de busca de coerência) em que os diferentes elementos são unificados. Nesse sentido, o autor conclui que: “(...) a memória é um elemento constituinte do sentimento de identidade (...)", um fator importante “(...) do sentimento de continuidade e de coerência de uma pessoa ou de um grupo em sua reconstrução de si (...)" (Pollack, 1992, p. 5). O autor ainda ressalta que "(...) memória e identidade podem perfeitamente ser negociadas e não são fenômenos que devam ser compreendidos como essências de uma pessoa ou de um grupo (...)", além de dependerem de critérios de admissibilidade e aceitabilidade em negociação com outros. 
Interrogar sobre a vida de trabalho, compreendendo o papel estruturante do trabalho na vida dos entrevistados, é, na verdade, perguntar por todos os eventos relevantes da vida. A partir da história, do exercício da memória, entendida como socialmente produzida, expressam-se identidade e cultura, individuais e coletivas, articulando sentidos, evidenciando um código, em que vida, trabalho e morte não se excluem.

As entrevistas realizadas foram reagrupadas, didaticamente, sobre os seguintes eixos temáticos, entendendo, no entanto, que estão articulados entre si: a descrição da localidade em seus primórdios, os primeiros empresários, os trabalhadores pioneiros, a sociabilidade entre patrões e empregados e a noção de saúde que se tinha à época (incluindo a ocorrência dos acidentes).

A compreensão da cultura, dos valores, dos sentidos, das histórias desses trabalhadores é uma forma de desnaturalizar discursos ainda freqüentes na região, que remetem os agravos à saúde e os acidentes de trabalho ao destino, à fatalidade, à vontade divina, ao risco "inerente" da atividade no setor de rochas ornamentais e, mais comumente, à "personalidade" do trabalhador (que seria teimoso, descuidado...). A desconstrução de tais discursos e práticas pode contribuir para a elaboração de políticas públicas de saúde visando à prevenção e à assistência tanto nos acidentes, quanto nas diversas enfermidades que acometem os trabalhadores dessa atividade.

\section{Da roça às rochas}

A cidade de Cachoeiro de Itapemirim, situada no sul do Estado do Espírito Santo, ostenta, não sem algum orgulho, o título de "Capital do Mármore" do país, o que traduz o crescimento econômico que o setor vem galgando ao longo do tempo. Para se ter uma idéia dessa importância, podemos compará-lo com a produção mundial: o Brasil ocupa o sexto lugar na produção mundial de rochas e revestimentos, atrás de China, Espanha, Índia, Irã e Itália, com uma produção em torno de seis milhões de toneladas ao ano, abrangendo cerca de 600 variedades em 500 locais de lavra. O setor de rochas ornamentais emprega atualmente cerca de 120 mil pessoas, das quais 60 mil estão no Espírito Santo, de acordo com Ministério da Ciência e Tecnologia. ${ }^{4}$

Atualmente, o setor de mármore e granito emprega formalmente em todo o Estado cerca de 20 mil trabalhadores, conforme o Sindicato dos Trabalhadores em Indústrias de Extração e Beneficiamento do Mármore, Granito e Calcário do Espírito Santo, estando de fora desse número os trabalhadores sem carteira assinada, terceirizados e clandestinos. São cerca de 1.600 empresas cadastradas - dessas, aproximadamente 1.200 estão localizadas no sul do Estado; 800 são micro e pequenas empresas, 350 são de médio porte e 50 são de grande porte. No período de janeiro a outubro de 2003, as exportações capixabas de rochas ornamentais somaram 183,69 milhões de dólares e 596.753,72 toneladas. Trata-se de um setor de grande complexidade, tanto do ponto de vista das diversas tarefas que opera, quanto das condições adversas em que elas se dão.

O município de Cachoeiro de Itapemirim possui cerca de 174.000 habitantes. Destes, 147.000 vivem na sede. Os distritos onde estão localizadas as jazidas e as empresas, tanto de extração quanto de beneficiamento, são bem menores. A localidade de Itaoca, por exemplo, que é um distrito cuja economia gira prioritariamente em torno do setor de rochas, possui 
cerca de 5.000 habitantes. Soturno, por sua vez, tem aproximadamente o mesmo número de habitantes e Gironda, 1.285 habitantes. $^{5}$

A atividade traz à região um complexo de desdobramentos: por um lado, dinamização da economia, realização anual da Feira Internacional do Mármore, com exposição, comercialização e exportação de chapas e produtos beneficiados do mármore e do granito, além de geração de empregos; por outro lado, a atividade promove uma degradação ambiental em função dos rejeitos da produção, agravos à saúde dos trabalhadores e acidentes fatais e mutiladores.

Do ponto de vista do trabalho, segundo Oliveira (2005), entre 01/01/1996 e 31/12/2004, ocorreram 73 acidentes fatais em todo o Estado, representando uma média de 8,1 acidentes por ano em um universo de cerca de vinte mil trabalhadores. De acordo com o autor, "(...) antes do Sindimármore, a categoria, que tinha cerca de cinco mil trabalhadores, tinha a mesma média de acidentes só no sul do Espírito Santo, particularmente no triângulo Cachoeiro, Castelo, Vargem Alta" (p. 163).

Os números revelam a grandeza do setor, mas escondem sua história e suas mazelas. Como se chegou a esses números? De onde vieram empresários e trabalhadores, ou melhor, como se constituíram como tais? De que tipos de instrumentos e de tecnologia se valeram para construir essa "potência"? Como enfrentaram os agravos à saúde relacionados com o trabalho? E os viventes, como viviam?

\section{Do mundo rural ao mundo das pedras: forjando uma atividade, uma localidade e uma categoria de trabalhadores}

Na década de 50, a economia do sul do Estado do Espírito Santo estava calcada, prioritariamente, no cultivo do café, na cultura de subsistência e na pecuária - uma economia agrária em dificuldades. Um antigo empresário entrevistado conta como era a vida antes de ingressar na atividade do mármore:

Aquele que estava trabalhando na roça, aquele que tinha colhido bastante algodão estava mais ou menos controlado; os outros estavam com muita dificuldade, trabalhando, plantando só milho, feijão, pezinho de café, mas era a conta da despesa do ano - no final do ano vendia aquilo pagava as dívidas, pagava o armazém onde ele comprou, ficava a zero de novo. Só tinha em casa a comida, dinheiro, não!

Os trabalhadores também não viam grandes vantagens em trabalhar na lavoura. Segundo relato de um trabalhador aposentado:

Se colhia o milho e ia vender, o negociante não pagava quase nada e aí a gente ficava trocando cebola, né? Aí eu falei com a mulher assim: "Está saindo serviço de pedra e eu acho que o dinheiro que a gente ganha na pedra é melhor um pouquinho, dá pra nós cumprir manter a casa e sobrar alguma coisa". Embarquei pra pedreira, né? Achei que deu uma melhorazinha, mas foi pior pra mim, porque tudo aconteceu [dois acidentes de trabalho].

A origem dos trabalhadores e de muitos empresários era a mesma: a roça, a lavoura, as dificuldades do campo. O trabalho na roça era difícil - um dos entrevistados começou aos seis anos carregando pequenos pedaços de cana para o plantio: "Andava com dificuldade. Mas

5 Dados obtidos no site da Prefeitura Municipal de Cachoeiro de Itapemirim. 
era muitas crianças, um anima o outro, né? A caninha, a gente botava assim nos braços e entregava às senhoras, elas é que sabiam plantar".

Eram trabalhadores do campo e não possuíam terras. O recurso, então, era trabalhar em terras alheias, aqui ou ali, onde houvesse trabalho. $\mathrm{O}$ motivo do ingresso na atividade mineradora era um só: as pedreiras davam um mínimo de dinheiro e, na roça, ao final do mês, depois de ter entregado sacos de produção, muitas vezes o trabalhador ainda devia ao patrão. Diferentemente dos trabalhadores, os que vieram a se constituir empresários eram antes donos de terras - os que foram entrevistados possuíam terras com ocorrência de pedras - e assim trocaram a atividade agricultora pela de extração.

\section{Os primeiros empresários da região}

As terras com ocorrência de pedras impossibilitavam o plantio de culturas, o que, nessa fase (anos 50 e 60), era considerado uma má sorte para o proprietário, de maneira que muitas terras com potencial de exploração de pedras foram negociadas a preços irrisórios. Um entrevistado, empresário do setor, conta: “(...) quando meu pai faleceu [em 1951], nós tinha quarenta alqueires de terra, então quem ficou com mais terra, área de terra, porque tinha pedra, não tinha como cultivar". Ou seja, ficaram com uma maior área de terra aqueles que pegaram por herança terras de difícil cultivo, justamente aquelas que tinham pedras.

O mesmo empresário conta como foi despertado seu interesse pelo setor:

Eu comecei, eu era agricultor, então eu tinha uma serraria de madeira, pica-pauzinho, né? Aí, depois, eu, vendo os outros tirar pedra, eu tinha propriedade que tinha pedra, achei que tinha que tirar também, né? Mas não tinha recurso.

Não ter recursos foi uma dificuldade também mencionada por outro empresário entrevistado:

Sabe que trabalhador da roça não tem crédito, não tem! O meu pai costumava dizer: "Meu filho, o homem vale na vida material, o homem vale o que ele tem. Se ele não tem nada, ele não vale nada". Homem de lavoura não tinha nada, não tem crédito, certo?

De maneira que, não tendo como investir em maquinário, pode-se dizer que a tecnologia era mesmo a força bruta. Um empresário entrevistado assim se manifestou:

Mas aí comecei a tirar, comprei uma marreta lá, comecei a tirar. Tipo artesanal. Tirar um bloco levava dez, quinze dias (...). embarcado depois na macaca, levava três, quatro horas para embarcar... Mas era gostoso, a gente trabalhava animado... [risos].

Esse entrevistado começou a atividade tendo um empregado, depois contratou outro. Aos poucos foi melhorando, teve três funcionários e assim por diante. Outro entrevistado fez a mesma coisa: "Nós começamos a arranhar aquilo com a mão, tirando bloco com a mão, carregando com guincho manual".

O empresário procedia às tarefas de coordenação do processo como um "encarregado" atual, mas não se furtava a pegar no trabalho "bruto". Além dessas, havia também as tarefas de contador, atendente e administrador:

(...) porque por aí, engraçado que eu fazia aquilo tudo, carregava o caminhão e depois eu ia lá, eu fiz um escritoriozinho lá, de madeira, né? Pra eu tirar as notas, eu tinha que fazer os 
cálculos tudo direitinho, tudo na mão, não tinha máquina, né? Tudo na mão e eu mesmo tirava a nota.

O que dependesse da utilização do telefone, como pedidos e encomendas, era feito após o expediente, quando o empresário chegasse à cidade de Cachoeiro de Itapemirim (local de sua moradia), porque em Soturno não havia linhas de telefone.

As dificuldades pelas quais passou resumiu em um evento para ele inesquecível: "Um dia eu fui lá, peguei o dinheiro pra pagar passagem ida e volta, ia pra lá de Guarapari buscar uma peça. Na volta, eu peguei um ônibus e pra mim vinha direto pra Cachoeiro, né?". Engano, pegou um ônibus errado e não tinha dinheiro para pagar outra passagem. A solução foi saltar do ônibus e pedir uma carona.

Vinha andando a pé, devagarzinho, você sabe que começou a querer anoitecer e ninguém parou e eu não tinha dinheiro pra pagar nada. O sol já estava escondendo, passou uma caminhonete, aí eu fir sinal, parou e me deu carona. Chegou a Cachoeiro, ele me deixou, eu ainda vim de Cachoeiro até aqui [Soturno] a pé.

O entrevistado quer evidenciar que as dificuldades por que passou no início tornam a comparação difícil de ser transposta para os dias de hoje. Eram sinais de uma época, de uma industrialização incipiente, iniciada com poucos recursos financeiros e de processo desconhecido para os próprios "industriais".

Nesse sentido, arrancar a pedra "à unha" tem um significado literal e metafórico. Não foi fácil também para o empresário, ainda mais o cachoeirense sem recurso, iniciar, desbravar a atividade. Ele repete a resposta de solicitação de crédito a um banco para a compra de um motor a diesel: "O senhor não tem crédito, não! Não tem crédito, não, pode ir embora!". As dificuldades aqui elencadas não excluem o prazer do exercício da atividade: "Mas foi isso, a vida foi gostosa em parte, né?". As dificuldades relatadas no desbravamento da região e da atividade trazem embutido o orgulho do "vencedor" a partir da ética do trabalho, significando um homem, além de bem-sucedido economicamente, honrado.

Questionado sobre como aprendeu aquilo tudo, respondeu prontamente: "Nunca fui na pedreira de ninguém. Eu sou meio sistemático, eu achava que, se eu isse na pedreira dos outros, eles podiam dizer: 'O que esse pilantra veio fazer aqui?'. Errei, acertei sozinho”. Ou seja, aprendeu a administrar um negócio com a experiência advinda do setor rural, sem noções de organização do trabalho e sem uma fundamentação administrativa um pouco mais rebuscada, sem conhecimento de leis do trabalho ou menos ainda sobre saúde e segurança no trabalho, em particular, na atividade que estavam iniciando.

\section{Os primeiros empregados}

A experiência dos trabalhadores iniciantes não era maior: "Eu comecei assim: entrei num dia, um cara me deu uma régua, falou: 'Vai montar o arame lá. [Mas] eu nunca tinha visto isso". O dono da pedreira argumentou: "Se você não for, eu boto outro! Você que vai medir, toma o metro! Se não der certo eu boto outro!". Então, o lavrador, futuro empregado de pedreira, não teve outro jeito senão: "Cheguei lá, medi... dai umas duas horas o fio já estava rodando, aí não sai mais...". O início de sua atividade também foi baseado em ensaio e erro e em improvisação. Importante é ressaltar que, embora trabalhadores e empresários tenham igualmente começado suas respectivas atividades pela técnica de ensaio e erro, os objetivos eram diferenciados: os empresários buscavam a produção do lucro e os trabalhadores a sobrevivência pela produção de trabalho. Há algo que o próprio episódio acima relatado 
evidencia e que marca as diferenças de posições, a questão do controle do processo de trabalho. Embora muitas vezes as tarefas e as dificuldades misturem empresários e trabalhadores nessa fase, o controle do processo do trabalho e as conseqüências desse fato estavam delineados.

A organização do trabalho - jornada, intervalo, ritmo - era ditada pela necessidade ou pelos imprevistos do momento. Assim, “(...) tinha hora para pegar, mas não tinha hora para largar". Isso podia implicar trabalhar mais de 24 horas sem dormir, sem descanso, o que foi exemplificado por um trabalhador aposentado:

Eu pegava hoje sete horas. Amanhã eu tinha que sair sete da manhã, 24 por 24. Difícil, né? Chuva, sol, lama, mas aí o meu encarregado falava assim: "Eu tenho uma mudança para descer... Vocês não podem ir embora, só quando vocês fazer o serviço". Então, eu pegava, furava aquilo, descia, arrumava o fio, botava pra gerar, depois ia embora. Aí eu chegava em casa já tarde. Naquele mesmo dia, quatro horas retornava!

Um sindicalista completa:

Eu lembro muito bem, eu era criança, o meu pai saía de manhã para trabalhar e não tinha hora pra chegar. Dava a noite, dava no outro dia de manhã e não chegava... às vezes mamãe mandava nós ir lá ver o que estava acontecendo, aí [o pai] mandava falar que ia ficar até mais tarde, às vezes chegava no outro dia, na parte da tarde em casa. Trabalhava o dia, a noite, o dia, trinta e tantas horas!

O processo de trabalho dependia quase exclusivamente da força, da coragem e da disposição dos homens: "Olha, pra você ter uma idéia, não tinha os guindastes que tem hoje pra carregar. Nós levava o dia todo pra carregar um caminhão encostado numa rampa um rolo debaixo do bloco". Não é exagero dizer que a "tecnologia" era a força bruta.

Quanto às condições de trabalho, já descritas como rudes, os trabalhadores resumiam sua indignidade no seguinte aspecto: "Nós trabalhava descalço, tem retrato aí...". Em diversas entrevistas, com trabalhadores aposentados, acidentados ou sindicalistas, a falta de botinas para trabalhar traduzia a ilegitimidade das condições de trabalho.

Tratava-se de processo de trabalho que, embora tenha a conotação negativa de bruto e rude, a sua execução conferia (e confere até hoje), de forma positiva, uma via privilegiada de provas de virilidade e honradez. Conforme relatado pelo mesmo entrevistado, dos cinco irmãos que o pai empregou num mesmo dia nas pedreiras "(...) ficou eu e um outro irmão". Conta com ironia os motivos da desistência dos outros:

Você estava trabalhando, o encarregado estava em cima de você aqui assim [mostra], aquelas caçambas, você cavando cascalho, jogando, e ele... [mostra o sujeito com a mão no queixo...] a água chega [mostra], a água ia pra ele tomar ali, oh... [risos] apanhava pra ele... O café ia pra ele ali... Menina, um solão!!!. Pegava sete da manhã às quatro da tarde, mas nós fomos heróis eu e meu irmão güentamos.

Não era qualquer um que agüentava o trabalho pesado e ainda suportava as dificuldades cavadas por encarregados que deveriam, por função, coordenar e facilitar o processo. A ironia relatada pelo trabalhador fica por conta do contraste entre a atividade contínua e penosa em que labutavam durante a jornada de trabalho enquanto o conforto da água e do café ia para o encarregado, compenetrado na arte da observação.

Do ponto de vista do processo do trabalho, o episódio evidencia os primórdios da divisão mais acentuada de homens e de tarefas; se antes eram o patrão e mais um empregado, depois outro, aqui há uma figura intermediária, a do encarregado. Funcionário para o patrão, e patrão para os funcionários, usufruía as benesses do café e da água, ficando o lado penoso 
do processo do trabalho para trabalhadores. Sua tarefa de coordenação do processo tem como objetivo a maximização da produção, entre outros meios, pela intensificação e extensão da jornada de trabalho, conforme relatado.

Do ponto de vista dos trabalhadores, suportar e superar as adversidades do trabalho, o aspecto penoso e o perigo transformam-se em valor: conferem a esses trabalhadores o atributo positivo de heróis. O mesmo trabalhador relata que, ao terminar a jornada de trabalho, sujava-se ainda mais do pó de mármore "(...) para passar em frente às moças, e elas apontava, é de pedreira, é de pedreira...", implicando um atributo positivo para chamar a atenção das possíveis namoradas.

O trabalho no setor não lhes dava de imediato o estatuto de trabalhador "fichado", isto é, com carteira assinada, muitos trabalharam anos sem o registro profissional. Eram trabalhadores que perambulavam ora na lavoura, ora em pedreiras, até se fixarem efetivamente num emprego formal, em geral, segundo depoimentos, já havia se passado cerca de três anos ou mais, como relata o entrevistado:

(...) porque logo nos começos essas firmas não assinavam carteira de ninguém, não. Nós entramos trabalhando, mas entrava assim... na moda 'vansimbora', igual na roça. Eles pagava por mês, mas sem documento assinado, sem nada.

Em outro depoimento, uma situação semelhante:

(...) com treze, quatorze anos, eu comecei a rodear as pedreiras de mármore, ajudando alguma coisa, assim clandestino, né? Clandestino eu trabalhei muitos anos (...), eu trabalhei assim voluntário, onde eu achasse serviço, um pouco na roça, um pouco no mármore, uma pedreira de calcita...

O mesmo trabalhador assinala: "A sede da gente mesmo era a carteira profissional, que seria muito difícil naquela época. Naquele tempo, quem adquirisse tinha que segurar mesmo". O entrevistado espanta-se com o descaso em relação ao documento nos dias atuais: "Agora é fácil (...). As pessoas até estraga a carteira, eu vejo aí!".

Os trabalhadores aposentados apontaram as inúmeras dificuldades com que se depararam em seu cotidiano: era o tempo do trabalho bruto, rude. Segundo um empregado aposentado:

(...) no início, o negócio era feio de cara, viu? Tudo desorganizado, né? Não tinha nada bem feito. E a gente trabalhando mesmo pra arriscar a vida, né? O serviço era muito pesado, um serviço bruto. Aí continuamos, estava trabalhando, estava pegando com a vida.

Surgem as contradições: o mesmo trabalhador que anteriormente havia relatado que o trabalho trouxe uma "melhorazinha", ao mesmo tempo perdeu três dedos e ficou cego de um olho. Era melhor trabalhar na pedreira do que no campo, embora o processo de trabalho no setor de rochas fosse desorganizado e, além de bruto e rude, “(...) pegava com a vida”. Aqui está explicitada a improvisação com que trabalhavam, potencializando os perigos e os riscos de morte. Nesse relato, em especial, o trabalhador reconhece que estava submetido a processo de trabalho em que corria risco de morrer.

Os trabalhadores aposentados não sabiam se era por entusiasmo da juventude, se porque eram homens, se porque não tinham juízo, mas todos relataram não ter medo dos riscos e tampouco desanimaram quando testemunharam acidentes fatais ou foram eles mesmos vítimas de acidentes. Parece que a percepção mais aguda do trabalhador aposentado sobre a desorganização e o risco de morte (marcado na expressão "pegava com a vida") decorre do fato de trazer no corpo a marca dessa possibilidade. Não só as marcas físicas, mas as dos sofrimentos decorrentes, conforme seu próprio testemunho: 
A senhora pensa bem: a gente perdendo uma peça do corpo igual a minha que é a única coisa que nós temos hoje, a pior coisa, que é ficar sem ela, é a vista, né? Eu perdi essa vista e veio me dizer a mim que eu não tinha direito de receber indenização (...). Eu não recebi nenhum tostão de nada. Nem da minha vista, nem destes dedos aqui. Não recebi nada!

A ilegitimidade e o conseqüente sofrimento sentidos pelo trabalhador pela falta de responsabilização e amparo por parte do empregador foi um tema recorrente nas entrevistas. No primeiro acidente que sofreu, evidenciaram-se a improvisação e o desrespeito aos trabalhadores: o entrevistado aposentado (antes de perder a visão) conta-nos que o acidente em que perdeu três dedos aconteceu

(...) no tempo da ignorância, porque aquilo quando vinha os material bruto que tem aí, guincho, tudo, não tinha preparo nenhum bom. Então, achava que dava pra ligar o guincho na energia, tudo achava [que era] conversa de encaixar duas fases. Então, nós estavam tombando uma prancha de pedra grande e o encarregado era meio grosseiro, né? Aí ele botou seis ou sete companheiro que estava embaixo para calçar a prancha de pedra e me botaram no guincho, coisa que eu nunca trabalhei, meu serviço foi sempre martelo.

Aqui o entrevistado nos fornece o contexto da ocorrência do acidente: era o tempo em que encarregados determinavam o processo de trabalho sem considerar a experiência e o preparo do trabalhador para determinados tipos de operações; era o tempo em que mandavam trabalhadores para funções diferenciadas daquela de origem, sem treinamento, utilizando maquinários defeituosos. Tais formas de gerência em uma pedreira é que tornam certos processos de trabalho uma "morte anunciada". Não era de se esperar outra coisa senão a ocorrência de acidente, com mutilação. Conforme o relato:

Aí a pedra começou tombando, não tinha freio, não tinha nada. E ele fazendo sinal de cima pra mim frear com a mão. Segurar com as mãos nas correias. Eu, quando vi os homens sumindo debaixo da prancha de pedra, vai acabar eu assassinar todo mundo ali, e eu que sou culpado! Eu levei a botina em cima das correias que freou um pouquinho, mas não deu, eu levei essa mão pra pegar, aí soltei a chave de (...) a chave caiu sozinha, aí pegou esses dedos na correia assim, entrou na polia isso aqui separou na hora (...).

Esse acidente aponta uma série de elementos que o caracterizam como previsível. Guinchos sem freios, trabalhador fora de sua função de origem, trabalhador que opera uma máquina sem preparo e que, mesmo avisando ao encarregado, é obrigado a fazê-lo. Não se segue a "morte anunciada", mas a perda de três dedos e muito sofrimento para o trabalhador e sua família. Como esse, encontram-se muitos. Acidentes previsíveis, cujos indícios estavam claros, inclusive para os próprios trabalhadores.

Quando na ativa, os trabalhadores referem que não sentiam medo, compartilhavam aquilo que Dejours (1994) chamou de estratégia coletiva de defesa, ou seja, minimizavam os riscos para continuar trabalhando. Entretanto, ao se aposentarem, todos eles relataram o medo e o pavor que passaram a ter do trabalho em pedreira. $\mathrm{O}$ mesmo trabalhador aposentado relatou-nos que, na sua vida de trabalho: "(...) eu não sentia medo nenhum, que eu era acostumado; se falasse 'a espoleta vai pocar', eu digo não, não e não. Limpei muito fogo!". No entanto, nos dias de hoje, "(...) quando acontece um fracasso qualquer [acidente], eu me sinto muito abalado". O mesmo trabalhador relata:

Eu trabalhei, muitas vezes eu fiquei amarrado numa rampa de pedra, daquela que até água pra mim ia lá amarrada numa corda [de tão alto] (...). Agora, hoje não. Hoje, uma alturinha assim que eu passo, parece que a cabeça está puxando (...) como é que eu fiquei assim?

Parece que, ao não compartilhar coletivamente com os colegas a minimização dos riscos, os aposentados passam a ter uma real dimensão do perigo das pedreiras. Uniram-se às 
mulheres no medo. Suas esposas (que também participaram das entrevistas) relataram que só faziam rezar e pedir a Deus que trouxesse seus maridos vivos das pedreiras. Agora o casal se une na mesma oração pra que seus filhos, que estão majoritariamente empregados nas atividades do setor de rochas ornamentais, retornem vivos também, conforme afirmou um entrevistado:

Tem vez de noite que a gente nem dormir direito a gente não dorme. Fica imaginando... Porque acontece com um, acontece com outro, a gente fica pensando, né? O acidente ocorrer, porque quando a gente menos espera, acontece um troço diferente na pedreira aí. Serviço de pedreira é serviço bruto mesmo! E a gente fica pensando nos filhos da gente, no serviço, né? Coitados, né? A gente pede a Deus, né? Porque todo dia a gente tem que rezar e pedir a Deus, pra eles e pra gente também que a gente já sofreu muito e os filhos estão lutando na vida.

O entrevistado tem quatro filhos empregados no setor, além de dois genros.

Se, no final da década de 60, ingressar no setor de rochas constituía uma opção alternativa às dificuldades do trabalho na lavoura, esses aposentados têm a noção de que hoje seus filhos se empregam em pedreira porque

(...) coitados, é porque o estudo deles é pouco... E hoje em dia o cara para achar uma melhora de serviço tem que ter estudo, né? Se não tiver estudo, não tem jeito. Tem gente, colega meu, estudado, que não acha outro serviço, tem que pegar pedreira, mesmo!

Mesmo com escolaridade um pouco melhor, fica difícil outra opção de trabalho. Além do mais, "(...) tem hora que eu fico falando mais a minha mulher: o único lugar do serviço do pobre é lá no alto da pedreira, porque, de caminhão que desce lá de cima, é tudo de lá que o serviço sai...". Resta pedir a Deus que retornem.

A entrada formal na pedreira dava ao sujeito o estatuto de "empregado" de alguém e conferia a idéia de segurança quanto à questão da sobrevivência. Muitas vezes a busca por esse estatuto de empregado vinha acompanhada da decisão de casar-se, com a constituição de família e a chegada dos filhos. Com esse novo status social (empregado e pai de família), o sujeito começa a construir a sua vida de homem honrado. Ser um bom marido e pai de família implicaria a provisão adequada do lar, além de ser "bom de serviço", que se entende em não faltar ao trabalho, não reclamar, não fazer "exigências", não botar "questã" em coisas miúdas e, principalmente, ter saúde e força física, emblemas de virilidade (Moulin, Reis \& Wenichi, 2001). A constituição da família e a inserção no trabalho são marcas apontadas por diversos autores como ancoradouros da cultura da classe trabalhadora (Almeida, 1995; Duarte, 1986; Hoggart, 1973).

Podemos constatar que tanto trabalhadores, quanto os patrões vinham da labuta da lavoura e vislumbravam no trabalho de extração e beneficiamento de pedras uma vantagem, uma possibilidade de melhorar a vida material. Tanto o empresário, quanto o trabalhador estavam em transição no que diz respeito à sua posição social. Estavam, melhor dizendo, construindo nova posição social (da roça às rochas), arcando com as conseqüências que tanto comportam orgulho, quanto as dores de um cotidiano de trabalho duro e, sobretudo, os acidentes que não tardaram a aparecer.

\section{A localidade de pedra}

Os entrevistados destacaram que não havia na região infra-estrutura que contemplasse a nova atividade. As estradas foram abertas com instrumentos rústicos, como 
facão, enxada e foice, conforme Salviano da Costa (1991). Luz elétrica também não havia, o que obrigou muitos deles a trabalharem à noite com lampiões. Se hoje as estradas que levam caminhões para as pedreiras em Itaoca ainda são de terra batida, na época, segundo um empresário:

(...) no início, a estrada afundava, quando começou a descer o primeiro bloquinho, o caminhão afundava por ai nessa terra, até que assolou, né? Ih! Tinha vez que o caminhão afundava, ficava uma semana aí, chovia o caminhão afundava. Ficava quinze dias atolado aí.

Para atrair trabalhadores para suas pedreiras, muitos proprietários construíram casas, as chamadas "casas de firma”, oferecendo assim condições mínimas de moradia. Dessa forma, um aposentado classificou como vantagem o fato de que o patrão: "(...) mandou que a gente fizesse casinhas boas pra gente morar, de tamanho que coubesse a família, à vontade, fazer aquilo que precisasse. Ele nos deu essa vantagem". Mais adiante, o mesmo entrevistado vai revelando: "Nunca tive casa assim [própria], não, porque, no caso, eu era encarregado e, sempre nos lugares que eu trabalhava, eles tinham uma casinha perto da pedreira". O que poderia ser uma possível vantagem se revela como instrumento para as necessidades da produção, do ponto de vista do capital:

O patrão fazia questão que a gente tivesse aquela casa pra morar bem perto da pedreira porque, a qualquer hora, carro pra carregar, de noite eu estava lá. Dia de domingo, feriado, qualquer hora. Até aconselhavam pra gente não sair de casa. Ficar mesmo escravizado.

Lopes (1976) também encontrou a expressão "cativeiro" para expressar a disponibilização do trabalhador para as demandas do processo de trabalho, mesmo fora do horário contratado de trabalho. As casas de firma guardam certa semelhança em suas funções, quando comparadas com as vilas operárias no início da industrialização brasileira. Segundo Piquet (1998):

A proximidade da produção e da reprodução assegura a assiduidade dos operários, assim como sua pontualidade. Esse duplo processo de subordinação da força de trabalho é, ainda, um elemento importante no estado de prontidão permanente do operariado, principalmente nas profissões relacionadas com a manutenção e os reparos de máquinas (p. 22).

O distrito de Itaoca era meio rural e hoje é um corredor de exportação de blocos, chapas e produtos beneficiados; ainda assim, até hoje, não mereceu nenhuma atenção especial por parte do poder público, embora gere receita considerável para os cofres da municipalidade. Por conseqüência, resta aos trabalhadores morar em locais de muita poeira e muito ruído provenientes das próprias empresas e constantes estampidos de detonações de pedra. Acrescenta-se que as acelerações e freadas freqüentes pela intensa movimentação de caminhões levantam ainda mais poeira, produzindo um tom enevoado na localidade e um ruído contínuo. Já ocorreu de um desses caminhões, ao descer carregado de pedras, perder o freio, entrar na casa de uma família e matar uma criança. De acordo com um morador entrevistado:

A menina que morreu teve praticamente um enterro simbólico, ela foi esmagada, parte do corpo dela. Já havia ocorrido um fato deste antes, o caminhão havia perdido o freio, desceu a serra, num horário de movimento. Por incrível que pareça, ele desceu, passou, caiu num córrego. Pra felicidade não atravessou ninguém.

No dia 5 de setembro de 2006, a mesma sorte não teve um menino, estudante de oito anos, que escorregou, caiu próximo à calçado, foi atropelado e morto por uma carreta de 
pedras, cujo motorista sequer percebeu o atropelamento, sendo parado pela força dos gritos dos moradores. ${ }^{6}$

Na região de Soturno, o empresário entrevistado conta que foi responsável não só pela construção das primeiras casas, como também pela construção de um cemitério e, ao longo dos anos, pela instalação de linhas telefônicas, pela construção de um posto médico, por ter conseguido um destacamento policial na região, por ter instalado um posto do Banco do Brasil dentro de sua empresa que atende a toda comunidade. Além disso, o mesmo empresário construiu ginásio de esportes, campo de futebol, área de lazer, auditório (para encontros religiosos), consultório odontológico e colocou ambulância à disposição da comunidade, o que foi confirmado por relatos de outros entrevistados e por Salviano da Costa (1991). Torna-se evidente a falta de investimentos do poder público em prover esses pequenos distritos de investimentos mínimos que requer uma população em formação.

Dessa maneira, os trabalhadores que iniciaram atividade no setor de rochas dependiam dos seus patrões, não apenas em função do salário, mas também para questões relacionadas com saúde, locomoção, moradia. Os distritos não tinham postos de saúde, os trabalhadores não tinham meios de transporte, iam para o trabalho montados em caçambas de caminhões repletos de pedras ou mesmo a pé. Seu teto também pertencia ao patrão. A importância de alguns empresários extrapolava as cercas das pedreiras, pois eles, por vezes, acumulavam as funções que deveriam ser do poder público - iluminação, escolas, assistência médica e hospitalar, enfim, as necessidades básicas de uma comunidade em formação.

Hoje, as pequenas comunidades são referidas positivamente pelos moradores, como fonte de solidariedade na hora de uma "precisão" - a rede de vizinhos, amigos, a parentela, as diversas igrejas, a amizade que construíram foram apontados como fatores preponderantes, não só nas horas difíceis, mas também como fonte de trocas afetivas e confiáveis. Mesmo assim, os moradores não deixaram de reconhecer os problemas relacionados com a poluição causada pelas empresas, pelo trânsito pesado de caminhões, pela falta de opções de lazer, pela falta de assistência médica tanto para a população em geral, quanto para a população trabalhadora em particular.

\section{Os "modos de andar a vida" de patrões e empregados}

Num primeiro momento, parece que as tarefas exercidas por trabalhadores e patrões pouco se diferenciavam - compartilhavam juntos da aventura de começar uma atividade, saídos da roça e labutavam também no desbravamento de uma região. O trabalho era duro para todos.

Trabalhadores em estreito contato com o patrão e, ao mesmo tempo, dependendo dele para tantas coisas, que na vida deveriam ser direitos básicos, fez com que esses direitos fossem vivenciados como uma vantagem devida ao patrão. Tal situação traz implicações no que diz respeito à construção da sociabilidade entre patrões e empregados, entre empresários e comunidade: há, por certo, maior dependência e sentimento de "gratidão" por parte do empregado e maior controle por parte do patrão. A distância e os limites entre patrão e empregado eram tênues, dando lugar a uma complexa e delicada relação de reciprocidade hierárquica, com relações de compadrio e de troca de favores, obscurecendo o fato de se tratar de uma relação de trabalho inserida num determinado processo de produção capitalista com suas respectivas contradições. 
Nos relatos dos trabalhadores aposentados, os patrões, muitas vezes, parecem ter a importância de um pai (pai-patrão, patriarca) ao qual se deve respeito e gratidão, enquanto o trabalho executado permanece invisível no resultado final, nos blocos retirados com perfeição, nas chapas polidas. Nos belos pisos de mármore, esconde-se o trabalho penoso e bruto; é como o lado não polido das chapas: é feio, desagradável ao toque e ficam invisíveis quando se transformam em bancadas de pias ou tampos de mesas. $\mathrm{O}$ trabalho era uma obrigação e devia ser executado de qualquer forma, chovesse ou fizesse sol, com ou sem riscos, como parte da relação estabelecida. Por outro lado, esperava-se do patrão mais do que um salário, o reconhecimento do sacrifício do trabalho penoso, representado por favores, como: cessão de casas, empréstimos (na forma de pequenos adiantamentos de salário) e, principalmente, que o patrão protegesse a família quando da morte ou mutilação em acidente de trabalho do seu empregado. Na quebra desse sutil contrato, os trabalhadores enxergavam ilegitimidade e sofrimento. Há, por certo, uma vivência, por parte de alguns, das relações de trabalho como "se fôssemos uma família"; diga-se de passagem, com tudo o que uma família pode comportar de solidariedade e sentimento de pertencimento, mas também de cerceamentos e dores.

\section{E a saúde?}

Ao longo do tempo, os acidentes fatais e mutiladores, desses que "esmagam um homem, arranca a cabeça e que fica como uma folha de papel", começaram a ter certa visibilidade social, em primeiro lugar nos lamentos de dor das viúvas, dos órfãos e de pais que perdiam seus filhos nessa atividade e, mais fortemente, a partir da constituição do sindicato dos trabalhadores em 1991, nas reivindicações dos sindicalistas por melhores condições de trabalho (Oliveira, 2005).

Mas a saúde, como uma questão a ser considerada no processo de trabalho, não era sequer cogitada por trabalhadores e empresários, nos primórdios da atividade. Um trabalhador aposentado ilustra a temática:

Esse problema de saúde é uma coisa difícil até da gente calcular daquela época pra agora, porque o patrão não teria nada com isso, com a saúde da pessoa. Nada, nada, absolutamente. A coisa corria assim, o operário só prestava se tivesse saúde para trabalhar. Essa é que é a verdade naquela época.

Infelizmente, nada muito diferente ocorre no mundo do trabalho nestes tempos pósmodernos. Ele continua seu relato:

(...) porque, se adoecesse era, como se diz, você e aquilo que você encontra na frente, o INSS, mas o patrão não se movia em nada. Isso antigamente. Se quebrasse uma perna, botava no carro, levasse... se morresse também levava lá pra Santa Casa ou cemitério, mandava chamar o médico pra tirar de dentro da propriedade e continuava o trabalho.

De fato, a saúde não era uma questão para essa população (muito menos para o patrão). Vê-se que nosso entrevistado desliza o assunto da saúde para os acidentes, ou seja, se nem nos acidentes que eram chocantes - porque deixavam graves e visíveis seqüelas no corpo ou matavam o trabalhador - atribuía-se responsabilidade aos patrões ou ao processo de trabalho, o que dizer de processos insidiosos, como a surdez ou a silicose, que são processos invisíveis e que se dão em espaço de tempo maior? 
Ali na roça, nas pedreiras, a discussão sobre saúde, sobre o direito à vida começa com o choro das mulheres e dos órfãos ouvidos, consolados e posteriormente organizados por religiosos nas celebrações e atividades da Igreja Católica de Vargem Alta, e ganha força nos anos 90. Organizaram-se em marchas chamadas "Caminhada dos Mártires do Mármore". Esse movimento culminou no processo de fundação do sindicato dos trabalhadores. Transitando de "heróis" a "mártires", os homens vão tecendo a sua história de trabalhadores.

\section{Conclusão}

Encontramos uma população de trabalhadores e de empresários que saem do mundo rural e levam para o trabalho na indústria uma visão de mundo do tipo tradicional, do fazendeiro e seus colonos, dando prosseguimento a uma gestão de trabalho baseada nessa cultura. Ambos (futuros trabalhadores e futuros empresários) entendem pertencerem a uma determinada ordem hierárquica e assimétrica, em relação de complementaridade ou reciprocidade (Duarte, 1983, 1986), com valores e princípios próprios. Aos patrões caberia a coordenação do processo social, não só no trabalho, mas na localidade e na própria vida pessoal dos empregados. Ele está na posição do senhor. Do ponto de vista dos trabalhadores, caberia a obediência. Em contrapartida, a pessoa parece pertencer àquele patrão que lhes confere não só o salário, mas até local de moradia e do qual se espera amparo nas horas difíceis. Está inserida socialmente, ao mesmo tempo, em oposição e em complementaridade ao patrão.

Outra característica desses trabalhadores em transição do rural para a indústria é que a noção de ser trabalhador se confunde com aquele que "não tem medo do serviço", "que não desanima", "que não tem tempo ruim", ou seja, uma pessoa que se submete às condições de trabalho, mesmo em situações de risco de morte, sem reclamar. O perigo e o risco de acidente eram minimizados ou vivenciados como parte inerente ao trabalho, ao qual os heróis do mármore pareciam imunes. A vivência de um acidente não os abalava; machucar-se ou morrer parecia parte do trabalho e da vida. A morte no trabalho não era enunciada como ilegítima - o que lhes parecia ilegítimo era o patrão não amparar a família num momento de "precisão", rompendo o acordo tácito entre os supostos "parceiros". Parceria essa que é desnudada no episódio do acidente: o patrão não é compadre, a pedreira não é casa, os colegas não são família e o trabalho era tão perigoso que resultou em um acontecimento trágico.

Em seu conjunto, essas características imprimem à população trabalhadora um tom resignado em face às contradições trazidas pelo processo de produção, em particular, pelos sucessivos acidentes de trabalho. Se, por um lado, expõem certa fragilização dos trabalhadores na defesa de suas vidas, na possibilidade de transformação concreta das condições de trabalho, essa visão de mundo encontra-se alicerçada em fortes marcas culturais - que conferem identidade positiva ao sujeito -, tais como o orgulho de ser trabalhador, de ser provedor de sua família, de ter saído do campo e de dar mostras de saúde e virilidade, de ser muitas vezes um "herói". É somente em oposição a uma identificação positiva tão duramente conquistada, compartilhada por suas famílias e pelos habitantes da localidade, que se pode compreender a submissão de trabalhadores a um processo de trabalho tão perigoso. Não se coloca em risco a possibilidade de perder o emprego, pois além da sobrevivência física, coloca-se em risco também a sobrevivência simbólica: perder essa estrutura de sentido seria a morte em vida. Nesse sentido, conforme uma viúva entrevistada, "morreu no trabalho, mas ninguém tem esperanças de morrer, todo mundo tem esperança é de viver". Os trabalhadores se arriscam a morrer, mas por esperança de viver. 


\section{Referências}

Almeida, M. V. de (1995). Senhores de si: uma interpretação antropológica da masculinidade. Lisboa: Fim de Século.

Ariès, P. (1989). Sobre a história da morte no ocidente: desde a Idade Média. Lisboa: Teorema.

Dejours, C., Abdoucheli, E. \& Jayet, C. (1994). Psicodinâmica do trabalho: contribuições da escola dejouriana à análise da relação prazer, sofrimento e trabalho. São Paulo: Atlas.

Duarte. L. F. D. (1983). O culto do eu no templo da razão. Boletim do Museu Nacional, 41, 1-69.

Duarte, L. F. D. (1986). Da vida nervosa nas classes trabalhadoras. Rio de Janeiro: Zahar.

Dumont, L. (1993). O individualismo: uma perspectiva antropológica da ideologia moderna. Rio de Janeiro: Rocco.

Freitas, C. M. de (2001). A análise de acidentes de trabalho em indústrias tendo como referência a organização do trabalho. In L. H. Borges, M. G. B. Moulin \& M. D. Araújo (Orgs.), Organização do trabalho e saúde: múltiplas relações. Vitória: Edufes/CCHN.

Halbwachs, M. (2006). A memória coletiva. São Paulo: Centauro.

Hoggart, R. (1973). As utilizações da cultura: aspectos da vida da classe trabalhadora, com especiais referências a publicações e divertimentos. Lisboa: Presença.

Jardim, S. R. (1997). O trabalho e a construção do sujeito. In J. F. Silva Filho \& S. R. Jardim (Orgs.), A danação do trabalho: organização do trabalho e sofrimento psíquico. Rio de Janeiro: Te Corá.

Lopes, J. S. L. (1976). O vapor do diabo: o trabalho dos operários do açúcar. Rio de Janeiro: Paz e Terra.

Minayo, M. C. de S. (1992). O desafio do conhecimento: pesquisa qualitativa em saúde. São Paulo: Hucitec.

Moulin, M. G. B. (2006). O lado não polido do mármore: a produção social dos acidentes de trabalho e suas conseqüências no setor de rochas ornamentais no sul do Estado do Espírito Santo. Tese de Doutorado, Fundação Oswaldo Cruz, Escola Nacional de Saúde Pública, Rio de Janeiro.

Moulin, M. G. B., Reis, C. T. \& Wenichi, G. H. (2001) Homens de pedra? Pesquisando o processo de trabalho e saúde na extração e no beneficiamento do mármore: relato de uma experiência. Cadernos de Psicologia Social do Trabalho, 3/4, 47-63.

Oliveira, J. I. de (2005). O grito das pedras: a romaria dos mártires do mármore. Cachoeiro do Itapemirim.

Piquet, R. (1998). Cidade-empresa: presença na paisagem urbana brasileira. Rio de Janeiro: Zahar.

Pollack, M. (1992). Memória e identidade social. Estudos Históricos, 5 (10), 200-212.

Salviano da Costa, I. L. (1991). Cachoeiro suas pedras sua história. Cachoeiro de Itapemirim.

Seligmann-Silva, E. (1994). Desgaste mental no trabalho dominado. Rio de Janeiro: Te Corá.

Silva Filho, J. F. et al. (1993). Organização do trabalho e saúde mental: estudo das relações entre a prevalência de doenças mentais e organização do trabalho no município do Rio de Janeiro. In Fórum de Ciência e Cultura da UFRJ, Textos para Discussão (n. 7). Rio de Janeiro: UFRJ.

Velho, G. (1994). Observando o familiar. In Individualismo e cultura: notas para uma antropologia da sociedade contemporânea (3a ed.). Rio de Janeiro: Zahar..

\section{Endereço para correspondência}

mgbmoulin@gmail.com

Recebido em: 28/09/2006

Revisado em: 08/02/2007

Aprovado em: 11/05/2007 